\title{
Uncapping of worker bee brood, a component of the hygienic behavior of Africanized honey bees against the mite Varroa jacobsoni Oudemans
}

\author{
Maria-Helena Corrêa-Marques ${ }^{\mathrm{a}^{*}}$, David De Jong ${ }^{\mathrm{b}}$ \\ ${ }^{\text {a} E n t o m o l o g y ~ S e c t i o n, ~ F a c u l d a d e ~ d e ~ F i l o s o f i a, ~ C i e ̂ n c i a s ~ e ~ L e t r a s, ~ U n i v e r s i d a d e ~ d e ~ S a ̃ o ~ P a u l o, ~}$ \\ 14.049-901 Ribeirão Preto, SP, Brazil \\ ${ }^{\mathrm{b}}$ Genetics Department, Faculdade de Medicina, USP, 14.049-900 Ribeirão Preto, SP, Brazil
}

(Received 18 January 1997; accepted 24 October 1997)

\begin{abstract}
Prematurely uncapped worker brood cells, possibly an initial phase of hygienic behavior, were found in ten Africanized honey bee colonies in Brazil. Among 360 such cells, $46 \%$ contained the mite Varroa jacobsoni. A mean of $12 \%$ of the normal, capped, worker brood cells were infested in the same colonies. In $18 \%$ of the uncapped cells there were feces of larvae of the greater wax moth (Galleria mellonella), but no indication of mites. The remaining cells had no signs of either, or of any other abnormality that might have provoked the bees to uncap the cells. White-bodied pupae, with lightly pigmented eyes were the phase most frequently found to be uncapped, and represented $53 \%$ of the total. The nearly four times higher infestation rate in prematurely uncapped cells shows that the bees selectively uncap cells infested with Varroa jacobsoni. (C) Inra/DIB/AGIB/Elsevier, Paris
\end{abstract}

Varroa jacobsoni / Africanized bee / resistance / Galleria mellonella / hygienic behavior

\section{INTRODUCTION}

Removal of infested brood is considered an important mechanism of resistance of the Asian honey bee Apis cerana Fabr. to the mite Varroa jacobsoni Oudemans $[18,19,20,22,25]$. The bees somehow detect the mite(s) and/or the damage that they cause to the bee pupa, uncap the cell and remove the parasitized brood. The odor of the mite itself influences this behavior. A. cerana is especially sensitive to $V$. jacobsoni artificially introduced from A.mellifera L. colonies. A. mellifera can

* Correspondence and reprints 
also detect and remove $V$. jacobsoni infested brood, but to a much lesser extent [22].

Africanized honey bees in the southern part of South America are resistant to $V$. jacobsoni and are maintained without any kind of treatment $[5,23]$. Infestation levels are lower in Africanized colonies than in European bees and first-generation European/Africanized hybrids kept under the same conditions $[6,10,11,15]$. This apparent resistance of the Africanized honey bees has been attributed to various factors, including reduced mite fertility [21], fewer mite progeny [2], lower infestations in the smaller brood cells of Africanized versus European honey bees $[9,12]$ and more efficient adult grooming behavior $[14,16]$. The infestation levels are in fact decreasing in the Africanized bee colonies in Brazil [17]. However the relative importance of these apparent resistance factors is still not clear, and other key factors may be involved.

Prematurely uncapped worker brood was occasionally found during a study of $V$. jacobsoni infestation rates of Africanized bee colonies [3]. As these cells often contained $V$. jacobsoni, we decided to examine them in order to determine if their being uncapped was a consequence of the Africanized bees, reaction to the mite infestation.

\section{MATERIALS AND METHODS}

The honey bee colonies used in this study were all Africanized, headed by queens captured in swarms, or by their descendants, kept in the University of São Paulo apiary in Ribeirão Preto, São Paulo state $(620 \mathrm{~m}$ altitude, $21^{\circ} 11^{\prime} 25^{\prime \prime}$ south latitude). The data for eight colonies were collected May-June 1995. These were selected by visually examining the brood patterns of 45 colonies for opened worker brood cells. An additional two colonies were examined in August 1997. These two had the most opened brood cells among 32 colonies examined during a 2-d period. All colonies were kept in single storey, standard deep ten- frame Langstroth hives, with 4-7 frames of brood. Initially a single colony, in which opened brood cells were noticeable, was examined ten times, during a period of 2 weeks. Each day three combs of sealed brood were removed and scanned visually for the presence of prematurely uncapped cells. Whenever a cell was found to be uncapped, it was examined carefully. A forceps was used to remove the pupa, with aid of a fibreoptic light to illuminate the interior of the cell. The cells and pupae were examined for $V$. jacobsoni and other foreign entities that might have provoked the premature uncapping. These pupae were also examined externally to search for abnormalities that could have provoked the bees to uncap the cells, and to determine the developmental phase of the pupae. The developmental phases were classified according to Issa [8] and Michelette and Soares [13] for Africanized honey bees: WP $=$ white pupa (with white eyes) 10.9-12.6 d; PEP = pink-eyed pupa (white body, pink to brown eyes) $12.6-15.7 \mathrm{~d}$; LP $=$ lightly pigmented pupa (brown eyes and lightly pigmented body) 15.7-18.4 days; $\mathrm{DP}=$ darkly pigmented pupa (with brown eyes) 18.4-19.2 d.

The other nine Africanized colonies, in which opened brood cells were found, were examined in the same way, though only two to three times each. The brood cells were classified into three distinct categories: 1) presence of $V$. jacobsoni, 2) pupa spotted with faeces of the greater wax moth $(G$. mellonella $\mathrm{L}$.) and 3) pupa with no damage, or partially removed, with no indication of $V$. jacobsoni or wax moths.

The $V$. jacobsoni infestation rate was determined for worker brood in all ten colonies. Sealed brood was analysed in 100 cells, 50 cells on each side of a comb.

\section{RESULTS}

A total of 360 brood cells were found prematurely uncapped. About half of these contained pupae with pink to brown eyes and white bodies (PEP, table I). The next most frequent stage found was lightly pigmented pupae with brown eyes (LP). About $7 \%$ of the cells contained pupae that were missing a head, and/or other body parts. These were classified as unde- 
Table I. Developmental phases of post-larval stage worker brood found uncapped in Africanized honey bee colonies.

\begin{tabular}{crrrrr}
\hline & \multicolumn{5}{c}{ Brood phase } \\
\cline { 2 - 6 } Colony \# & WP & PEP & LP & DP & UD \\
\hline 44 & 1 & 26 & 2 & 0 & 0 \\
46 & 0 & 5 & 1 & 1 & 0 \\
47 & 2 & 5 & 3 & 0 & 0 \\
55 & 0 & 16 & 13 & 0 & 0 \\
73 & 1 & 11 & 19 & 1 & 0 \\
113 & 4 & 20 & 11 & 1 & 0 \\
117 & 0 & 5 & 2 & 0 & 3 \\
137 & 1 & 66 & 25 & 13 & 11 \\
143 & 1 & 31 & 31 & 10 & 9 \\
169 & 1 & 7 & 0 & 0 & 1 \\
\hline Total & 11 & 192 & 107 & 26 & 24 \\
\hline$\%$ of total & 3.06 & 53.33 & 29.72 & 7.22 & 6.67 \\
\hline
\end{tabular}

Developmental phases of the pupae: WP, white pupa; with white eyes; PEP, pink-eyed pupa (eyes pink to brown, with a white body); LP, lightly pigmented pupa with brown eyes; DP, darkly pigmented pupa with brown eyes; UD, undefined, pupa partially removed, without possibility of determining developmental phase.

fined (UD), as it was not possible to verify the brood development stage. The differences in the proportions of the pupal developmental phases found in these uncapped cells were highly significant (test for $n$ proportions [7].

About $53 \%$ of the uncapped cells with intact pupae contained $V$. jacobsoni, or signs of the mites (table $I I$ ). Most of these contained the original female mites with progeny. A few contained only mite progeny, without the original mother mites, which had apparently left. In others only 'fresh' mite faeces were present, indicating that the mites had left (or been removed) after the bees had uncapped the cells. All of the cells containing only adult female mites, also had normal quantities of mite faeces, indicating that none of these were infested after the cells were uncapped.
The mean brood infestation rate among the ten colonies was $11.9 \%$, significantly less than the infestation rate of the prematurely uncapped cells in the same colonies $(P<0.05$, binomial test, and test for $n$ proportions [7]). This implies that the bees selectively uncapped brood cells containing $V$. jacobsoni.

About $18 \%$ of the cells contained pupae covered with faeces of the greater wax moth, Galleria mellonella. Rarely, the wax moth larvae were seen. A few were collected and reared to adult to confirm the species identification. Some bee pupae had only a small amount of faeces, others were nearly completely covered. No cells were found containing both $V$. jacobsoni and wax moth faeces. The remaining cells (about $36 \%$ ) had no sign of $V$. jacobsoni or wax moths. As there was no indication of damage, it was 
Table II. Varroa jacobsoni infestation in worker brood (100 cells examined per colony), number of prematurely uncapped brood cells found, and abnormalities found in these cells.

\begin{tabular}{|c|c|c|c|c|c|}
\hline \multirow{2}{*}{ Colony \# } & \multirow{2}{*}{$\begin{array}{c}V . \text { jacobsoni } \\
\text { infestation } \\
\text { rate in } \\
\text { brood }(\%)\end{array}$} & \multirow{2}{*}{$\begin{array}{l}\text { Number of } \\
\text { uncapped } \\
\text { brood } \\
\text { cells }\end{array}$} & \multicolumn{3}{|c|}{$\begin{array}{l}\text { Abnormalities } \\
\text { found in the brood cells }\end{array}$} \\
\hline & & & V. jacobsoni & $\begin{array}{l}\text { Wax moth } \\
\text { faeces }\end{array}$ & None \\
\hline 44 & 10 & 29 & 14 & 11 & 4 \\
\hline 46 & 10 & 7 & 4 & 3 & 0 \\
\hline 47 & 10 & 10 & 8 & 0 & 2 \\
\hline 55 & 3 & 29 & 0 & 10 & 19 \\
\hline 73 & 6 & 32 & 4 & 8 & 20 \\
\hline 113 & 2 & 36 & 5 & 9 & 22 \\
\hline 117 & 4 & 10 & 2 & 2 & 6 \\
\hline 137 & 25 & 116 & 71 & 14 & 31 \\
\hline 143 & 28 & 82 & 48 & 9 & 25 \\
\hline 169 & 21 & 9 & 8 & 0 & 1 \\
\hline Total & & 360 & 164 & 66 & 130 \\
\hline$\%$ of total & & & 45.6 & 18.3 & 36.1 \\
\hline
\end{tabular}

not clear why they were uncapped by the bees, though it is possible that early instar wax moth larvae had passed through these cells without leaving faeces. Less than $1 \%$ of the 'normal' sealed brood cells examined for $V$. jacobsoni infestation contained wax moth faeces (data not shown), so it is apparent that attack by the wax moths also significantly $(P<0.05$, binomial test, and test for $n$ proportions [7]) influences the tendency to uncap the brood cells.

\section{DISCUSSION}

The prematurely uncapped cells may represent an initial phase of the response to brood that has been damaged or otherwise disturbed. These cells would be found at a much lower frequency in colonies that quickly removed the pupae from the uncapped cells. The colonies in which uncapped pupae are found in greater number could be deficient in this second phase of the removal process.
The worker brood cells found uncapped were considerably (nearly four times) more infested with $V$. jacobsoni than the 'normal' capped brood cells. If the bees continued this removal process and destroyed the mites, or at least destroyed the nymphal stages, then this uncapping behavior would help the bees keep the mites in check. This may be one of the factors responsible for the ability of Africanized bees to tolerate $V$. jacobsoni $[4,15]$.

The uncapping of the infested brood cells can be regarded as a part of what has been called hygienic behavior. Spivak et al. [24] found that colonies that had been selected for good hygienic behavior removed a significantly higher percentage of pupae artificially infested with $V$. jacobsoni, than did non hygienic colonies.

Boecking et al. [1] found that most removal of infested brood occurred before the mite progeny had reached the adult stage, as we found in our study. Also Boecking et al. [1] found that the bees were 
more likely to remove brood from cells containing two adult female mites, compared to cells containing only one mite. In our colonies multiple infestations of a single cell are extremely rare.

We can conclude that Africanized $A$. mellifera have the capability to recognize and uncap worker brood infested with the mite $V$. jacobsoni. This same behavior is evidently invoked when greater wax moth larvae attack the brood. The fact that the pupae were still intact in most of the cells, and many still contained $V$. jacobsoni, shows that either this defensive response of the bees is incomplete, or that this behavior occurs in stages, with other bees completing the task.

\section{ACKNOWLEDGEMENTS}

The authors thank João José dos Santos for help in the apiary. CNPq provided a fellowship for DDJ. CAPES and FAPESP provided graduate scholarships for M.H.C.M. Research funds were provided by CNPq and FINEP.

Résumé - La désoperculation du couvain d'ouvrières, un élément du comportement hygiénique des abeilles africanisées contre l'acarien Varroa jacobsoni. Les abeilles africanisées (A. mellifera $\mathrm{L}$.) sont connues pour être résistantes à l'acarien parasite Varroa jacobsoni Oudemans. Une étude détaillée du couvain d'ouvrières dans des colonies d'abeilles africanisées à Ribeira Preto, S.P., Brésil, a montré que dans certaines colonies les nymphes désoperculées étaient courantes. Beaucoup de ces colonies renfermaient des varroas, ce qui nous a incité à examiner ces cellules pour voir si les abeilles désoperculaient de préférence les cellules de couvain infestées par $V$. jacobsoni. Sur 360 cellules de nymphes d'ouvrières désoperculées, trouvées dans dix colonies d'abeilles africanisées, $46 \%$ d'entre elles renfermaient $V$. jacobsoni (tableau II). On a estimé que les cellules renfermaient $V$. jacobsoni lorsqu'on trouvait 1) des femelles adultes de l'acarien avec leur descendance (c'était la plupart des cas) ou 2) leur descendance seule ou des femelles adultes seules avec des fèces frais d'acarien ou 3) des fêces frais d'acarien seuls (indiquant que l'acarien femelle était parti ou avait été éliminé). Le stade de développement des nymphes a été déterminé dans les cellules de couvain désoperculé : $53 \%$ étaient des nymphes blanches avec des yeux roses à bruns et $30 \%$ des nymphes légèrement pigmentées avec des yeux bruns (tableau I). Dans ces colonies $12 \%$ en moyenne des cellules normales et operculées de couvain d'ouvrières étaient infestées. Dans $18 \%$ des cellules désoperculées on a trouvé des fèces de la grande fausse-teigne (Galleria mellonella L.) mais aucun signe de $V$. jacobsoni. Puisque moins d' $1 \%$ des cellules normales operculées de couvain d'ouvrières présentait des signes de fausse-teigne, il apparaît évident que les abeilles désoperculent sélectivement le couvain infesté par $G$. mellonella. Les autres cellules ne présentaient aucun signe anormal quelconque qui ait pu entraîner la désoperculation par les abeilles. Le taux d'infestation presque quatre fois plus élevé des cellules désoperculées prématurément montre que les abeilles désoperculent sélectivement les cellules infestées par $V$. jacobsoni. (C) Inra/ DIB/AGIB/Elsevier, Paris

Varroa jacobsoni / abeille africanisée / résistance / comportement hygiénique / Galleria mellonella

Zusammenfassung - Öffnen des Zelldeckels, eine Komponente des HygieneVerhaltens von afrikanisierten Honigbienen gegen die Milbe Varroa jacobsoni Oudemans. Von afrikanisierten Honigbienen ist bekannt, daß sie gegen die para- 
sitische Milbe Varroa jacobsoni resistent sind. Aus Untersuchungen der Arbeiterinnenbrut in Ribeirao Preto, SP, Brasilien ging hervor, daß in einigen Völkern häufig Puppen ohne Zelldeckel zu finden sind. Viele von diesen enthielten Varroa jacobsoni. Das veranlaßte uns, solche Zellen zu überprüfen und zu bestimmen, ob Bienen bevorzugt die von Milben befallenen Zellen öffnen. Bei insgesamt 360 entdeckelten Zellen, die wir in zehn afrikanisierten Völkern fanden, enthielten 46 $\%$ Varroa jacobsoni (Tabelle II). Zellen wurden als befallen gewertet, wenn sie adulte Milbenweibchen mit Nachkommen (die meisten Fälle), nur Nachkommen, nur Weibchen mit frischem Kot oder nur frischen Kot enthielten. (Frischer Kot zeigt an, daß das Weibchen die Zelle verlassen hatte oder entfernt wurde.) Das Entwicklungsstadium der Puppe in entdeckelten Brutzellen wurde bestimmt; 53 \% der Puppen hatten weiße Körperfarbe und rosa oder braune Augen und $30 \%$ waren leicht pigmentiert mit braunen Augen (Tabelle I). Im Mittel waren in diesen Völkern $12 \%$ der normalen verdeckelten Arbeiterinnenbrut befallen. In $18 \%$ der entdeckelten Zellen fanden sich Kot und Larven der großen Wachsmotte (Galleria mellonella $\mathrm{L}$.), aber keine Anzeichen von Varroa jacobsoni. Da in weniger als $1 \%$ der normal verdeckelten Brut Zeichen der Wachsmotte zu finden war, scheinen die Bienen gezielt Brutzellen zu entdeckeln, die von Wachsmotten befallen sind. Die restlichen Zellen zeigten weder Befall noch irgend eine andere Abnormalität, die das Entfernen des Zelldeckels hervorgerufen haben könnte. Die etwa viermal höhere Infektionsrate von vorzeitig entdeckelten Zellen zeigt, daß Bienen gezielt den Deckel von Brutzellen entfernen, die von der Milbe Varroa jacobsoni befallen sind. @ Inra/DIB/AGIB/Elsevier, Paris

Varroa jacobsoni / afrikanisierte Bienen / Resistenz / Galleria mellonella / Hygieneverhalten

\section{REFERENCES}

[1] Boecking O., Rath W., Drescher W., Apis mellifera removes Varroa jacobsoni and Tropilaelaps clareae from sealed brood cells in the tropics, Am. Bee J. 132 (1992) 732-734.

[2] Camazine S., Differential reproduction of the mite Varroa jacobsoni (Mesostigmata, Varroidae) on Africanized and European honey bees (Hymenoptera, Apidae), Ann. Entomol Soc. Am. 79 (1986) 801-803

[3] Corrêa-Marques M.H., Aspectos da resistência da abelha Apis mellifera ao ácaro Varroa jacobsoni no Brasil, M.Sc. thesis. Entomology Section, Faculdade de Filosofia, Ciências e Letras, Universidade de São Paulo, Ribeirão Preto, SP, Brasil, 1996, 137 pp.

[4] De Jong D., Africanized honey bees in Brazil, forty years of adaptation and success, Bee World 77 (1997) 67-70.

[5] De Jong D., Gonçalves L.S., Morse R.A., Dependence on climate of the virulence of $\mathrm{Var}$ roa jacobsoni, Bee World 65 (1984) 117-121.

16] Engels W., Gonçalves L.S., Steiner J., Buriolla A.H., Issa M.R.C., Engels E, Varroa-Beffal von carnica-Volkern in Tropenklima, Apidologie 17 (1986) 203-216.

17] Fleiss J.L., Statistical Methods for Rates and Proportions, 2nd ed., John Wiley and Sons, New York, 1981.

[8] Issa M.R.C., Estudo dos padrões protéicos e enzimáticos do ácaro Varroa jacobsoni e das abelhas hospedeiras Apis mellifera carnica e Apis mellifera de raça africanizada em populações da Alemanha e do Brasil, Ph.D. thesis. Faculdade de Medicina de Ribeirão Preto, Universidade de São Paulo, Ribeirão Preto, 1992. 119 pp.

[9] Issa M.R.C., De Jong D., Gonçalves L.S. Reproductive strategies of the mite Varroa jacobsoni (Mesostigmata, Varroidae), Influence of larva type and comb cell size on honey bee brood infestation rates, Braz. J. Genet. 16 (1993) 219-224

[10] Mendoza M.R.Q., Delgado S.G., Villasboa H.R.D., Investigacion comparativa de la incidencia del acaro Varroa jacobsoni Oudemans sobre distintas razas y lineas de abejas Apis mellifera L en el Paraguay, Depto. de Apicultura. Universidad Nacional de Asuncion, San Lorenzo, Paraguay. misc. publication, 1987. $6 \mathrm{pp}$.

111] Message D., Aspectos reprodutivos do ácaro Varroa jacobsoni e seus efeitos em colonias de abelhas africanizadas, Doctoral thesis, Genetics Dept., Faculdade de Medicina, University of São Paulo, Ribeirão Preto, 1985, 117 pp.

[12] Message D., Gonçalves L.S., Effect of the size of worker brood cells of Africanized honey 
bees on infestation and reproduction of the ectoparasitic mite Varroa jacob soni Oud, Apidologie 26 (1995) 381-386.

[13] Michelette E.R., Soares A.E.E., Characterization of preimaginal developmental stages in Africanized honey bee workers (Apis mellifera L). Apidologie 24 (1993) 431-440.

[14] Moretto G., Gonçalves L.S., De Jong D., Africanized bees are more efficient at removing Varroa jacobsoni - Preliminary Data, Am. Bee J. 131, 1991, 434.

[15] Moretto G., Gonçalves L.S., De Jong D., The effects of climate and bee race on Varroa jacobsoni Oud infestations in Brazil, Apidologie 22 (1991) 197-203.

[16] Moretto G., Gonçalves, L.S., De Jong D., Heritability of Africanized and European honey bee defensive behavior against the mite Varroa jacobsoni, Braz. J. Genet. 16 (1993) 71-77.

[17] Moretto G., Pillati A., De Jong D., Gonçalves L.S., Cassini F.L., Reduction of Varroa infestations in the State of Santa Catarina, in Southern Brazil, Am. Bee J. 135 (1995) 498-500.

[18] Peng Y.S.C., Xu S., Ge L., The resistance mechanism of the Asian honey bee, Apis cerana Fabr., to an ectoparasitic mite, Varroa jacobsoni Oudemans, J. Invertebr. Pathol. 49 (1987) 54-60.

[19] Peng Y.S.C., Fang Y., Xu S., Ge L., Nasr M.E., Response of foster Asian honeybee (Apis cerana Fabr.) colonies to the brood of European honeybee (Apis mellifera $\mathrm{L}$ ) infested with the parasitic mite, Varroa jacobsoni Oudemans, J. Invertebr. Pathol. 49 (1987) 259-264.

[20] Rath W., Drescher W., Response of Apis cerana Fabr towards brood infested with Varroa jacobsoni Oud and infestation rate of colonies in Thailand, Apidologie 21 (1990) 311-321.

[21] Ritter W., De Jong D., Reproduction of Varroa jacobsoni $\mathrm{O}$. in Europe, the Middle East and tropical South America, Z. Angew. Entomol. 98 (1984) 55-57.

[22] Rosenkranz P., Tewarson N.C., Singh A., Engels W., Differential hygienic behaviour towards Varroa jacobsoni in capped worker brood of Apis cerana depends on alien scent adhering to the mites, J. Apic. Res. 32 (1993) 89-93.

[23) Shimanuki H., Knox D., De Jong D., Bee diseases, parasites and pests, in: Spivak M., Fletcher D.J.C., Breed M.D. (Eds.), The African Honey Bee, Westview Press, Boulder, Colorado, 1991, pp. 283-296.

[24] Spivak M., Reuter G.A., Melton R., Breyfog]e P., Honey bee hygienic behavior and tolerance to Varroa jacobsoni, in: Proceedings of the American Bee Research Conference, Am. Bee J. 134 (1994) 836-837.

[25] Tewarson N.C., Singh A., Engels W., (1992) Reproduction of Varroa jacobsoni in colonies of Apis cerana indica under natural and experimental conditions, Apidologie 23, 161-171. 